\title{
A tribute to Dr Vittorio (Orio) Giarini, 31 January 1936-28 February 2020. A great European and a close friend
}

\author{
Walter R. Stahel ${ }^{1,2}$
}

Accepted: 24 February 2021 / Published online: 29 March 2021

(c) The Geneva Association 2021

Professor Dr Vittorio Giarini-Orio-was a restless researcher extraordinaire, a convinced federalist and European, a prolific worker with an open mind for new trends of thought and a gentleman of the twentieth century! A modest and discreet 'business angel' in the research domain, Orio was able to communicate in the major European languages (including Swiss German); he was an open, warm, patient and generous person, a promoter and mentor of students and economic researchers.

Orio's main themes were uncertainty and insurability. His death in Trieste on 28 February 2020 not only deprived him of contributing to the discussions around SarsCoV-2; COVID-19 also made it impossible for his next of kin and friends to attend his funeral. If I had to choose a motto for Orio, it would be a quote from David Spiegelhalter: ${ }^{1}$

Uncertainty is the engine of science, and a sign of knowledgeable humility.

Italian by origin, he studied economics at the University of Austin, Texas, and served as Secretary General of the European Federalist Movement in Paris from 1962 to 1967 before moving to Geneva, where he married and settled down. In his active life, he succeeded in combining the best of the four cultures.

In the late 1960s, Orio joined the Centre for Techno-economic Research of the Battelle Institute Geneva and, as assistant to Hugo Thiemann, its Director General, organised the first conference of the Club of Rome in 1970 in Bern-he went on to become a member of the club. Orio was the driving force behind the foundation of the International Association for the Study of Insurance Economics (The Geneva Association (GA)) in 1973, with the support of Fabio Padua Schioppa, CEO

\footnotetext{
1 https://www.theguardian.com/commentisfree/2020/nov/26/pandemic-earn-trust-facts-vital-covid?utm_ source $=$ Nature + Briefing \&utm_campaign $=$ bdd2fb01a0-briefing-dy-20201126\&utm_medium $=$ email $\&$ utm_term=0_c9dfd39373-bdd2fb01a0-42533343
}

Walter R. Stahel

wrstahel2014@gmail.com

1 Faculty of Engineering and Physical Sciences, University of Surrey, Guildford, UK

2 Circular Economy Research Centre (CERC) of École Des Ponts Business School, Marne-la-Vallée, France 
Generali, and Professor Raymond Barre, ${ }^{2}$ who became the first president of the GA. In his first report to the Assembly of Members in 1974, Professor Barre stated the Association's aims: "The Geneva Association has been founded to make an original contribution to the progress of insurance through objective studies of the interdependence between the economic environment and insurance activities. [...] in order to achieve this aim, The Geneva Association shall highlight the role of insurance in the economy and in modern society. For, at a time when the need for security is increasingly acute, it is in the interest of all parties to stand together to face the growing risks of a changing world." Almost 50 years later, this objective has lost nothing of its actuality.

National insurance organisations had existed for a long time before the GA was founded, for example the German Association for Insurance Science (Deutscher Verein für Versicherungswissenschaft e.V.). Founded in 1899 and with approximately 1,000 corporate and personal members today, its members include experts from academia and insurance practice, insurance supervision and jurisdiction, legislative bodies, associations and consumer protection organisations, as well as liberal professions.

Academic organisations such as AIDA $^{3}$ founded in 1960, also existed before the foundation of the GA, but with narrow objectives, such as promoting the scientific study of international and foreign national insurance law and strengthening the international scientific exchange of ideas and knowledge of the international legal development of insurance law.

Orio Giarini's idea for the GA was different: to create an exclusive club of CEOs of major insurance companies who would meet once a year for peer group discussions on advanced economic research topics relevant for insurance. As its first Secretary General, Orio developed the GA into the renowned think tank of the global insurance industry, seconded by brilliant young professors of economics such as Denis Kessler, ${ }^{4}$ who acted as Vice Secretary General and part-time collaborator of the GA.

As founder and editor of The Geneva Papers on Risk and Insurance, in which this article appears, and the first Professor of Service Economics at the Graduate Institute of European Studies of the University of Geneva, Orio was relentlessly promoting the aims of the GA, sketching a novel view of economics and discussing the key role of insurance and insurability in the emerging service economy.

In 1973, I joined Battelle at the same time as Orio left as director of the technoeconomic research division to start the GA-we were like two ships passing in the night. Two years later, while researching data for my study on 'the potential for substituting manpower for energy' (Stahel and Reday 1981), I interviewed several former Battellistes, including Orio. He immediately grasped the essence and potential

\footnotetext{
${ }^{2}$ Vice-President of the European Commission in Brussels 1967-1973; French Prime Minister 19761981.

3 https://aidainsurance.org/

${ }^{4}$ Chairman of the board of directors and Chief Executive Officer of SCOR since 2002. Member of the Académie des Sciences Morales et Politiques since 2016.
} 
impact of the idea and invited me to write several paragraphs on this topic for inclusion in his new book, Dialogue on Wealth and Welfare: An Alternative View of World Capital Formation; A report to the Club of Rome (Giarini 1980). We had often discussed the book's message when it was a work in progress; to me as an 'industrial analyst', 5 the findings looked convincing, even obvious, but despite the fact that Orio had been a member of the Club of Rome since its foundation, his ideas did not seem to penetrate into the core of the economic thinking of the members.

In 1982, Orio helped me to found the Product-Life Institute Geneva, which was independent of, but domiciled at, the GA. In 1986, Orio invited me to join him part-time at the GA as head of a new risk management research programme, studying industrial vulnerability and risks in engineering. As my nomination had to be accepted by the acting GA president, Professor Dr Dr Reimer Schmidt in Aachen, I spent a day at his office discussing risk topics. This was my first contact with the world of insurance CEOs, which I would share for the next 28 years. From then onwards, I split my time between the GA and 'my' fledgling Product-Life Institute, with the common objective of 'prevention'-loss prevention and waste prevention, respectively. I had the huge privilege of sharing ideas, work and a small office located in a two-room apartment at 18 Chemin Rieu in Geneva with Orio. The other room housed the GA secretariat and a XEROX copier on which all GA publications were printed. This machine produced the highest number of photocopies of any XEROX equipment in Geneva, a fact that illustrates how prolific Orio was as a writer and author, in addition to the task of managing the GA, with its rapidly growing number of members, and analysing numerous publications and journals on a daily basis.

Orio Giarini was The Geneva Association, and the small GA office was itself an image of Orio's focus on the essential, of his modesty and efficacy; it was a melting pot of ideas and a meeting point of personalities of the 'Genève International'. Orio's main tools were his typewriter, telephone and fax machine; the office was visited by less than a handful of GA members every year. It served as a base for producing a permanent flow of GA publications, which were sent to members, and for organising the annual General Assemblies and the seminars of the research programmes. Orio permanently filtered news items and ideas with relevance for insurance, uncertainty and insurability. Relevant ideas were discussed and rapidly transformed into publications, integrated into research programmes, such as the Risk Management and the Four Pillars Programmes, or into new structures, such as the World Fire Statistics Centre. Orio's strategy was to launch new fields of research and develop them until they became mainstream and then move on.

The early GA exhaled the spirit of Battelle, which was then the leading contract research organisation worldwide, where researcher-entrepreneurs developed innovative solutions to industrial and scientific problems. Sharing the office with Orio, I had many occasions to admire his ability and diplomacy, but also his frustrations in juggling the conflicting demands of individual members with his own vision, which

\footnotetext{
${ }^{5}$ I had studied architecture and regional planning at ETH Zürich, but this is how Orio used to describe my activity.
} 
was often not shared by all CEO members of the GA. Some of Orio's ideas on insurability took 20 years to be accepted as business opportunities by insurers and as topics by policymakers. Over time, our cooperation became increasingly symbiotic; I was nominated Vice Secretary General of the GA and, when Orio travelled, gave his lectures on the service economy at the Graduate Institute of European Studies. In the late 1980s we co-wrote the book The Limits to Certainty - Facing Risks in the New Service Economy (Giarini and Stahel 1989). ${ }^{6}$ While Orio continued working with telephone and fax, typewriter and paper, I used a PC and logically took over the typing of the manuscript and its production on camera-ready film, which enabled us to shorten the time to print by six months. It was only 30 years later that I realised the impact of this book, when Alan Rozen ${ }^{7}$ mentioned in a recent discussion that he had known my ideas for a long time, for when he had started a job at OECD in Paris his superior asked him to read 'The Limits to Certainty' before doing anything else.

Orio's way of 'learning by fostering new ideas' pushed us permanently into researching new domains. While conducting interviews in London on my pet idea of an economy in loops, I had met Maurice Goldsmith, director of the International Science Policy Foundation (ISPF), the 'science of science'. Orio seized the occasion and offered to publish a special issue of Maurice's journal Science \& Public Policy on our ideas under the title The Hidden Wealth (Goldsmith 1986), which included invited articles by Paul Ekins, ${ }^{8}$ a young British economist, on guaranteed basic income schemes. Next, the GA became home to the European section of the ISPF, with Sir Hermann Bondi ${ }^{9}$ as president and me as secretary, with the task of bringing together scientists from East and West. Orio had sensed the opportunity to explore new dimensions of the interdependence between different economic environments and insurance activities, as 'insurance' in the East was radically different from that in the West.

The GA and ISPF Europe began organising joint Science Meetings, helped by Charles P. Enz, Professor of Physics at the University of Geneva. We identified top scientists from both sides of the Iron Curtain and invited them to meet in a remote location to discuss a single topic for three days, with no notes taken. The participants were seated in a big circle, facing each other, empty handed; mobile phones did not yet exist.

The first GA science meeting was organised at the Castello di Duino near Trieste on the subject 'Nuclear Disarmament after Geneva'. ${ }^{10}$ Among the participants were

\footnotetext{
${ }^{6}$ Published in 1989 in English by Kluwer Academic Publishers and translated into numerous languages.

7 Professor of Innovation and Management and Dean of the École des Ponts Business School, Marne-laVallée.

8 Professor Paul Ekins, OBE, is currently co-director of the U.K. Energy Research Centre and Professor of Resources and Environmental Policy at University College London.

9 Sir Hermann Bondi, 1919-2005, KCB, FRS, was an Austrian-British mathematician and cosmologist. He is best known for developing the steady state model of the universe with Fred Hoyle and Thomas Gold as an alternative to the Big Bang theory.

10 The Geneva Summit of 1985 was a Cold War-era meeting in Geneva, held on 19 and 20 November between U.S. President Ronald Reagan and Soviet Secretary General Mikhail Gorbachev. The two leaders met for the first time to hold talks on the arms race and other diplomatic topics. Reagan suggested destroying $50 \%$ of all nuclear weapons, only to be topped by Gorbachev's proposal to destroy $100 \%$.
} 
Jack Steinberger, Nobel Laurate working at CERN; Abdus Sala-n, ${ }^{11}$ Nobel Laurate; Professor Hans-Peter Dürr; ${ }^{12}$ and leading physicists from the USSR. Many participants had known each other by name, some had read the others' publications, but they had never met. The result of the meeting was surprising: nuclear disarmament is mathematically impossible. The world will have to live with the uncertainty and the uninsurable risk this creates.

The second GA science meeting on the topic of superconductivity was held at the Gulbenkian Foundation in Lisbon, with the leading scientists on this topic worldwide, theoretical physicists working on the quest for a magic formula, scientists researching superconductive materials and engineers building medical equipment using superconductive components. Again, participants knew each other's publications but had never met. The result of this meeting was highly relevant for the GA: it enabled the risks and opportunities for insurers to be judged, which had previously only been known to insiders. The meeting thus helped to determine the uncertainty around the topic of superconductivity.

The third GA science meeting was held by invitation of the Hungarian Academy of Sciences; the fourth and final science meeting on the topic of life sciences was organised together with The international Council of Scientific Unions (ICSU) on the future of gene technology and held in Bratislava in 1990. As scientists from East and West could now travel and meet freely, the science meetings ended here. Of these science meetings, only participants' mental records exist.

Until then, the GA had a role to play in research because only a few major re/ insurers had their own research centres. The majority of GA members were CEOs from medium-sized insurance companies and Orio was able to inspire members with new insights on the topic of insurability. Researcher, author, editor, lecturer, manager, financier, he used his position and connections at the GA to advance his understanding of the changing world of risk of the last quarter of the twentieth century, and to attract young scholars, for instance by establishing the annual Geneva Association Ernst Meyer Prize, awarded for university research work in the form of a doctoral thesis that makes a significant and original contribution to the study of risk and insurance economics. The science meetings and the Ernst Meyer Prize were typical of Orio's entrepreneurial motivation to build bridges between disciplines and to better understand uncertainty and the future of insurance.

In the 1990s, as geographical scope (and membership of the GA) rapidly expanded, Orio decided to hire a full-time personal assistant. In addition, he wanted to rewrite 'The Limits to Certainty' with a focus on employment and engaged Patrick Liedtke, a young German researcher, who started by transforming Orio's manuscript into the book The Employment Dilemma: Report to the Club of Rome (Giarini and Liedtke 1987).

I continued my activity as head of risk management research within the GA. At the end of the second Millennium, this domain took on a new dimension for the insurance world, when in 1999 the Millennium bug produced a situation of

\footnotetext{
11 Director of the International Atomic Energy Agency's Centre for Theoretical Physics at Trieste.

12 Director of the Max Plank Institute for Astrophysics in Munich.
} 
pure uncertainty in IT. Then, in 2001, 9/11 constituted a black swan event, ${ }^{13}$ the unknown-unknown, which, combined with an economic crisis, questioned the sufficiency of insurers' financial reserves and underlined the importance of the risk management function in insurance. This resulted in the creation of the new role of Chief Risk Officer, ${ }^{14}$ which had previously only existed in banking. When Orio retired in 2000/01, the GA had changed from a European club of equals to a global forum; membership had grown to $80 \mathrm{CEOs,} \mathrm{the} \mathrm{research} \mathrm{focus} \mathrm{from} \mathrm{insurance} \mathrm{to} \mathrm{financial}$ services including insurance, and Patrick Liedtke was elected as second Secretary General of the GA at the General Assembly held in Zürich.

Orio soon left Geneva to return to his native Trieste, but retirement was no option for his creative researcher's mind. In 2001, he founded the Risk Institute to promote studies on risk and uncertainty and their impact on society; in 2003, he published a last book The Double Helix of Learning and Work with Mircea Malitza (Giarini and Malitza 2003) and in 2005 started the European Papers on the New Welfare.

In June 2006, Orio Giarini's work was finally recognised when he was inducted into the Insurance Hall of Fame by the International Insurance Society Inc. ${ }^{15}$ as 'the developer of an insurance institute'. To qualify for inclusion in the Insurance Hall of Fame, nominees must be judged to have made a lasting contribution to the insurance industry, for instance by having shown creative thinking and imaginative actionsstarting trends, discovering new products or methods, or uncovering and resolving problems.

It remains a mystery to me why Orio's contributions to the development of such concepts as the service economy and insurance economics have never received academic recognition. Maybe his holistic view of the economy did not fit into the silos of scientific disciplines?

In 2010, 10 years after his retirement, Orio wrote down the history of the GA, which only he could remember in detail. ${ }^{16}$ It is probably the best account of the birth of the GA and its first quarter century of activity. As trustee of the World Academy of Art and Science (WAAS), Orio promoted the Cadmus Journal ${ }^{17}$ and continued his research and writing until 2019 at the International University Institute for European Studies (Gorizia, University of Trieste). Until his death, he was a Fellow of WAAS in Trieste, and Director of The Risk Institute, Geneva.

Orio was a great mentor and friend. He broke down barriers of economic thought; his academic insights will survive through his books and scholars carrying

\footnotetext{
13 The Black Swan: The Impact of the Highly Improbable is a 2007 book by author and former options trader Nassim Nicholas Taleb.

14 Dr Bruno Porro, at Swiss Re, was the first insurance CRO.

15 The Insurance Hall of Fame, occasionally referred to as the International Insurance Hall of Fame, honours exceptional members of the insurance field. It was created in 1957 and is administered by the global non-profit International Insurance Society (IIS), which was founded in 1965 and is based in New York City.

16 https://www.genevaassociation.org/sites/default/files/publications-document-type/pdf_public//sys_ ga2011-iesc2.pdf

17 http://cadmusjournal.org/user/5
}

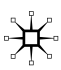


forward his legacy of wisdom. His warm personality will remain in the memory of his friends and students.

\section{References}

Giarini, O. 1980. Dialogue on wealth and welfare, a report to the Club of Rome. Oxford: Pergamon Press. Giarini, O., and P. Liedtke. 1987. The employment dilemma: Report to the Club of Rome. Rome: The Club of Rome.

Giarini, O., and M. Malitza. 2003. The double helix of learning and work. Rome: UNESCO.

Giarini, O., and W.R. Stahel. 1989. The limits to certainty - facing risks in the new service economy. Dordrecht: Kluwer Academic Publishers.

Goldsmith, M., ed. 1986. The hidden wealth. Special issue. Science \& Public Policy 13 (4): 184-253

Stahel, W.R., and G. Reday. 1981. Jobs for tomorrow, the potential for substituting manpower for energy. New York: Vantage Press. Reprint of the final report of research contract no 76/13-V/343/78-EN under the programme of research and actions on the development of the labour market, DGV, Commission of the European Communities, Brussels.

Publisher's Note Springer Nature remains neutral with regard to jurisdictional claims in published maps and institutional affiliations.

\section{About the author}

Walter R. Stahel is an architect by training (ETH Zürich), a researcher and industrial analyst by experience, a risk manager by necessity, and Visiting Professor at the Faculty of Engineering and Physical Sciences of the University of Surrey by invitation. He received a Doctor honoris causa from 1'Universite de Montréal and the University of Surrey, and works today as a successful author and keynote speaker by conviction, full member of the Club of Rome, member of several Scientific Advisory Boards, and Senior Research Fellow at the Circular Economy Research Centre of the École des Ponts Business School in Paris. 